\title{
Updating and Developing Information System CV X
}

\author{
Muhammad Raihan Nur*, Magnaz Lestira Oktaroza \\ Prodi Akuntansi, Fakultas Ekonomi dan Bisnis, Universitas Islam \\ Bandung, Indonesia. \\ *mreihannur111@gmail.com, ira.santoz@gmail.com
}

\begin{abstract}
CV X is a trading company that sells various types of packaging. This company runs its business activities with an order system. Problem which faced by CV X in carrying out its operational activities are the unclear duties, roles, functions and responsibilities in each section due to the absence of an organizational structure and written job descriptions, incomplete documents in terms of availability and format, and the report of each section is not generated. The purpose of this research is to design a sales, purchasing, and delivery \& assembly information system, so as to reduce the constraints and risks in carrying out its business activities. The method used in this research is the Framework For Application Of System Technique (FAST), by going through the System Development stage, the data collection technique is using Joint Application Development (JAD). The results obtained from the design of information systems carried out by researchers in the form of information system designs such as sales, purchasing, shipping and assembly information systems, documents and reports from each section, and the interface of the proposed information system, which is expected to assist operational activities. The company can run more effectively and efficiently because of good internal control.
\end{abstract}

Keywords: $C V X$, Effective and Efficient, Information System Design

Abstrak. CV X merupakan sebuah perusahaan yang bergerak di bidang perdagangan yang menjual berbagai macam jenis dari packaging. Perusahaan ini melakukan kegiatan bisnisnya dengan sistem by order. Kendala yang dihadapi oleh CV X dalam menjalankan kegiatan operasionalnya yakni tidak adanya kejelasan tugas, peran, fungsi dan tanggung jawab di setiap bagian karena tidak adanya struktur organisasi dan job description secara tertulis, kurang lengkapnya dokumen dari segi ketersediaan dan formatnya, dan laporan dari setiap bagian tidak dibuatkan. Tujuan dibuatnya penelitian ini adalah untuk dilakukannya perancangan sistem informasi penjualan, pembelian, dan pengiriman \& perakitan, sehingga dapat mengurangi kendala maupun risiko dalam menjalankan kegiatan bisnisnya. Metode yang digunakan dalam penelitian ini adalah Framework of the Application System Technique (FAST), dengan melalui tahapan System Development, yang teknik pengumpulan datanya menggunakan Joint Application Development (JAD). Hasil yang diperoleh dari perancangan sistem informasi yang dilakukan oleh peneliti, yaitu berupa rancangan sistem informasi seperti, sistem informasi penjualan, pembelian, pengiriman dan perakitan, dokumen dan laporan dari setiap bagian, dan interface dari sistem informasi yang diusulkan, yang diharapkan dapat membantu kegiatan operasional perusahaan agar berjalan lebih efektif dan efisien karena baiknya pengendalian internal yang diterapkan.

Kata Kunci: $C V X$, Perancangan Sistem Informasi, Efektif dan Efisien. 


\section{A. Pendahuluan}

Transformasi digital adalah suatu hal yang tidak bisa dihindari di zaman saat ini. Banyak perusahaan-perusahaan di Indonesia pun yang mulai memodifikasi proses bisnisnya menjadi digital. Digital disini yang paling umum adalah dimana alur bisnis dari perusahaan menggunakan komputer ataupun gadget lainnya seperti laptop, handphone dan smart gadget lainnya. Bahkan perusahaan perusahaan ternama sekarang sudah memiliki server sistem perusahaan pribadinya masing masing. Hal ini semua bertujuan untuk memperlancar dan mendorong kinerja dari setiap bagian dari perusahaan yang menghasilkan kegiatan penmasukan data, pemrosesan data, dan pengambilan data menjadi efektif dan efisien sejalan dengan tujuan dari database management system (DBMS).

Hal ini terealisasi dengan cepat akibat melandanya bencana wabah yang menimpa seluruh negara di dunia ini dimana seluruh proses bisnis yang menggunakan mobilitas untuk menjalankan usahanya mau tidak mau harus mulai bertransformasi. Dengan kondisi seperti ini, perusahaan yang tidak melakukan tranformasi digital dalam aktivitas bisnisnya maka perusahaan tersebut tidak akan berkembang dan akan melemah bahkan mati karena kalahnya daya saing oleh perusahaan yang sudah terlebih dahulu melakukan transformasi digital.

Proses bisnis yang diterapkan sebelum adanya bencana wabah ini memang lebih aman baik untuk perusahaan maupun konsumen. Namun ada beberapa kekurangan yang terjadi jika sistem informasi yang dijalankan dari suatu perusahaan tertentu masih menyangkut dengan banyak tenaga kerja yang menyebabkan kurangnya pengawasan atas kegiatan bisnisnya. Oleh karenanya perusahaan sering mengalami beberapa kerugian. Kerugian disini bisa dalam hal kehilangan aset fisik, maupun informasi yang umumnya dialami oleh perusahaan dagang besar, dan menengah.

CV X adalah sebuah perusahaan penyuplai barang yang bergerang dibidang packaging. Perusahaan ini berlokasi di Jl. Sindang Sari II No. 53 Kelurahan Antapani Wetan, Kecamatan Antapani, Kota Bandung, Jawa Barat. Perusahaan ini menyediakan berbagai macam jenis packaging dari mulai berbahan kayu, triplek, karton, kardus dan lainnya dimana biasanya konsumen yang membeli barang memerlukan kuantitas yang sangat banyak. Perusahaan ini pun memiliki banyak mitra kerjasama dengan supplier lainnya.

Dari hasil wawancara yang telah dilakukan dengan direktur CV X terdapat beberapa kendala dan masalah yang terjadi dalam perusahaan tersebut seperti tidak adanya struktur organisasi secara tertulis, prosedur bisnis yang terlihat samar-samar, job description yang kurang jelas, pemisahan tugas pokok, peran dan fungsi karyawan yang terlaksana dengan kurang baik, pengawassan oleh direktur yang masih minim karena masih berpegang teguh pada kepercayaan dari setiap karyawan, dokumen yang dipakai masih kurang baik dari segi ketersediaannya dan format yang tidak sesuai dengan standar.

Selanjutnya dari hasil survei diperoleh informasi bahwa terdapat beberapa masalah yang terjadi di bagian penjualan dimana tidak ada dokumen pada saat menerima pesanan, dan format dari surat jalan yang kurang lengkap, dan tidak ada laporan penjualan sehingga jika ada kendala tidak bisa dipertanggungjawabkan aktivitas yang telah dilakukan di bagian penjualan. Di bagian pembelian diperoleh informasi bahwa dokumen Order Pembelian (purchase order) yang kurang lengkap formatnya, dan tidak ada laporan pembeliannya. Di bagian perakitan diperoleh informasi bahwa tidak ada dokumen dan laporan yang dibuat dari setiap kegiatan perakitan ini namun hanya ada catatan-catatan di buku pribadi milik bagian perakitan.

Dengan ini, peneliti merancang sistem informasi pada proses bisnis dengan bersungguhsungguh yang bertujuan untuk membantu memudahkan dalam aktivitas operasional pada CV $\mathrm{X}$ agar lebih baik, efektif dan efisien, sehingga peneliti melakukan penelitian yang berjudul :

"UPDATING AND DEVELOPING INFORMATION SYSTEM CV X".

Tujuan penelitian ini yaitu :

1. Mengamati dan memahami bagaimana sistem informasi akuntansi yang digunakan oleh CV X.

2. Mengamati dan menganalisis kekurangan yang terdapat pada sistem informasi akuntansi yang digunakan kemudian menyarankan solusi perbaikan terhadap kekurangan tersebut. 
3. Membuat model perancangan system informasi akuntansi yang sesuai untuk diterapkan pada CV X.

\section{B. Metodologi Penelitian}

Metode deskriptif analisis dan studi kasus merupakan metode yang digunakan dalam penelitian ini. Penelitian deskriptif bertujuan untuk memahami gambaran ciri-ciri dari suatu kejadian/situasi maupun objek lainnya sebagaimana yang dikemukakan oleh Sekaran dan Bougie [1]. Selain itu, Liz Taylor [2] menjelaskan bahwa "The case study approach involves in-depth investigation of a contemporary case within a real-life setting. The case may be a person, a group of people, an organization, an event, or a project." Berdasarkan pendapat di atas pendekatan studi kasus melibatkan penyelidikan mendalam dari kasus kontemporer dalam pengaturan kehidupan nyata dimana kasus dapat berupa seseorang, sekelompok orang, organisasi, peristiwa, atau proyek. Dalam penelitian ini data yang diambil yaitu melalui sumber data primer dimana data diambil melalui hasil wawancara dan observasi secara langsung dengan beberapa pihak dari CV X. Untuk tahapan analisis sistemnya, penelitian ini dilakukan melalui tahapan pengembangan sistem yang menggunakan metode pengembangan sistem Framework for the Application of System Technique (FAST) dengan pendekatan Joint Application Development (JAD).

Tahapan didalam proses pengembangan sistem informasi adalah suatu kegiatan yang akan membawa proyek kepada suatu kondisi dimana keputusan manajemen dibutuhkan untuk melanjutkan atau tidak melanjutkan proyek tersebut. Tahapan-tahapan dalam proses pengembangan sistem yang baik memerlukan adanya tahapan tahapan seperti perencanaan, penganalisisan, pendesainan, penerapan dan pendukung sistem sebagaimana yang dikemukakan oleh Whitten [3].

Berdasarkan pendapat Whitten proses pengembangan sistem yang baik memerlukan adanya tahapan-tahapan pengembangan seperti perencanaan sistem, analisis sistem, desain sistem, implementasi sistem, dan pendukung sistem.

\section{Hasil Penelitian dan Pembahasan}

\begin{tabular}{|c|c|c|c|}
\hline No. & Sistem yang digunakan & $\begin{array}{c}\text { Rekomendasi sistem oleh } \\
\text { penulis }\end{array}$ & Alasan \\
\hline \multicolumn{4}{|c|}{ Model Struktur Organisasi dan Job Description } \\
\hline 1. & $\begin{array}{l}\text { Tidak ada struktur } \\
\text { organisasi secara tertulis. }\end{array}$ & $\begin{array}{l}\text { Membuatkan struktur } \\
\text { organisasi secara tertulis. }\end{array}$ & $\begin{array}{l}\text { Agar setiap bagian fungsi } \\
\text { organisasi dapat } \\
\text { bertanggung-jawab } \\
\text { terhadap peran dan } \\
\text { tugasnya masing- } \\
\text { masing. }\end{array}$ \\
\hline 2. & $\begin{array}{l}\text { Tidak jelasnya batasan } \\
\text { batasan tugas dari setiap } \\
\text { bagian sehingga aktivitas } \\
\text { di beberapa bagian kurang } \\
\text { efektif. }\end{array}$ & $\begin{array}{l}\text { Membuatkan uraian tugas (job } \\
\text { description) yang jelas dan } \\
\text { tertulis. }\end{array}$ & $\begin{array}{l}\text { Agar jelas batasan } \\
\text { batasan tugas dan } \\
\text { tanggung jawab di setiap } \\
\text { bagian yang ada di } \\
\text { perusahaan. }\end{array}$ \\
\hline
\end{tabular}




\begin{tabular}{|c|c|c|c|}
\hline 3. & $\begin{array}{lr}\text { Tidak adanya } & \text { fungsi } \\
\text { keuangan } & \text { tertulis } \\
\text { sehingga } & \text { bagian } \\
\text { penjualan dan } & \text { pembelian } \\
\text { merangkap } & \text { sebagai } \\
\text { bagian keuangan. } & \end{array}$ & $\begin{array}{l}\text { Membuatkan fungsi keuangan } \\
\text { di struktur organisasi dan di job } \\
\text { description. }\end{array}$ & $\begin{array}{lr}\text { Agar bagian } & \text { penjualan } \\
\text { dan bagian } & \text { pembelian } \\
\text { tidak lagi } & \text { merangkap } \\
\text { sebagai } & \text { bagian } \\
\text { keuangan, } & \text { dan } \\
\text { mengusulkan } & \text { agar } \\
\text { bagian } & \text { keuangan } \\
\text { dipegang oleh direktur. }\end{array}$ \\
\hline \multicolumn{4}{|c|}{ Model Sistem dan Prosedur Informasi Penjualan } \\
\hline 1. & $\begin{array}{l}\text { Tidak adanya prosedur } \\
\text { pembuatan dokumen } \\
\text { order penjualan pada saat } \\
\text { menerima surat pesanan } \\
\text { dari buyer. }\end{array}$ & $\begin{array}{l}\text { Memperbaharui prosedur } \\
\text { pembuatan dokumen order } \\
\text { penjualan dengan desain yang } \\
\text { memenuhi standar dokumen. }\end{array}$ & $\begin{array}{l}\text { Agar detail penjualan } \\
\text { yang dilakukan dapat } \\
\text { diketauhi oleh beberapa } \\
\text { bagian yang dapat } \\
\text { memudahkan proses } \\
\text { bisnis dan menerapkan } \\
\text { prosedur pengendalian. }\end{array}$ \\
\hline 2. & $\begin{array}{l}\text { Tidak adanya prosedur } \\
\text { pencocokan dokumen } \\
\text { atau barang yang diterima } \\
\text { dengan dokumen yang } \\
\text { ada. }\end{array}$ & $\begin{array}{l}\text { Memperbaharui prosedur } \\
\text { pencocokan dokumen atau } \\
\text { barang dengan dokumen yang } \\
\text { telah diarsipkan. }\end{array}$ & $\begin{array}{l}\text { Agar pengendalian dapat } \\
\text { diterapkan sehingga } \\
\text { memperkecil risiko dari } \\
\text { ketidak-sesuaian } \\
\text { dokumen/barang yang } \\
\text { diterima. }\end{array}$ \\
\hline 3. & \begin{tabular}{llr} 
Prosedur & \multicolumn{2}{r}{ pembuatan } \\
dokumen & surat jalan \\
dilakukan & oleh bagian \\
penjualan. & &
\end{tabular} & $\begin{array}{l}\text { Memperbaharui prosedur di } \\
\text { bagian penjualan yakni } \\
\text { pembuatan dokumen surat } \\
\text { jalan dilakukan oleh bagian } \\
\text { pengiriman dan perakitan. }\end{array}$ & $\begin{array}{l}\text { Agar tugas dan fungsi di } \\
\text { bagian penjualan dapat } \\
\text { berjalan dengan } \\
\text { maksimal dan efektif } \\
\text { karena tidak adanya } \\
\text { penumpukan tugas yang } \\
\text { seharusnya } \\
\text { dikerjakan oleh bagian } \\
\text { lain. }\end{array}$ \\
\hline 4. & $\begin{array}{l}\text { Beberapa dokumen di } \\
\text { bagian penjualan kurang } \\
\text { memenuhi randar } \\
\text { dokumen yang baik dan } \\
\text { benar. }\end{array}$ & $\begin{array}{l}\text { Memperbaharui dokumen di } \\
\text { bagian penjualan sesuai } \\
\text { dengan standar dokumen yang } \\
\text { baik dan benar. }\end{array}$ & $\begin{array}{lr}\text { Agar informasi } & \text { yang } \\
\text { dihasilkan dari } & \text { setiap } \\
\text { dokumen tidak rancu dan } \\
\text { informatif sehingga } \\
\text { membanturan proses } \\
\text { pengambilan keputusan } \\
\text { bagi perusahaan. }\end{array}$ \\
\hline 5. & $\begin{array}{lr}\text { Tidak } & \text { adanya } \\
\text { pendistribusian } & \text { dokumen } \\
\text { ke bagian lain. } & \end{array}$ & $\begin{array}{l}\text { Memperbaharui prosedur di } \\
\text { bagian penjualan dengan } \\
\text { melakukan pendistribusian } \\
\text { dokumen ke bagian lain. }\end{array}$ & $\begin{array}{l}\text { Agar aktivitas bagian } \\
\text { penjualan } \\
\text { terkendali dan terawasi } \\
\text { oleh beberapa bagian } \\
\text { yang ada di perusahaan. }\end{array}$ \\
\hline
\end{tabular}




\begin{tabular}{|c|c|c|c|}
\hline 6. & $\begin{array}{l}\text { Tidak adanya } \\
\text { pembuatan } \\
\text { penjualan di } \\
\text { penjualan }\end{array}$ & $\begin{array}{l}\text { Memperbaharui prosedur di } \\
\text { bagian penjualan dengan harus } \\
\text { melakukan pelaporan seluruh } \\
\text { kegiatan penjualannya ke } \\
\text { dalam laporan penjualan. }\end{array}$ & $\begin{array}{l}\text { Agar aktivitas di bagian } \\
\text { penjualan } \\
\text { dipertanggung-jawabkan } \\
\text { oleh bagian penjualan } \\
\text { terutama } \\
\text { direktur. }\end{array}$ \\
\hline \multicolumn{4}{|c|}{ Model Sistem dan Prosedur Informasi Pembelian } \\
\hline 1. & $\begin{array}{l}\text { Beberapa dokumen di } \\
\text { bagian pembelian kurang } \\
\text { memenuhi standar } \\
\text { dokumen yang baik dan } \\
\text { benar. }\end{array}$ & $\begin{array}{l}\text { Memperbaharui dokumen di } \\
\text { bagian penjualan sehingga } \\
\text { memenuhi standar dokumen } \\
\text { yang baik dan benar }\end{array}$ & \begin{tabular}{lr} 
Agar informasi & yang \\
dihasilkan dari & setiap \\
dokumen tidak rancu dan \\
informatif sehingga \\
membanturan \\
pengambilan & keputusan \\
\multicolumn{2}{l}{ bagi perusahaan. }
\end{tabular} \\
\hline 2. & $\begin{array}{l}\text { Tidak adanya prosedur } \\
\text { pencocokan dokumen } \\
\text { atau barang yang diterima } \\
\text { dengan dokumen yang } \\
\text { ada. }\end{array}$ & $\begin{array}{l}\text { Memperbaharui prosedur } \\
\text { pencocokan dokumen atau } \\
\text { barang dengan dokumen yang } \\
\text { telah diarsipkan. }\end{array}$ & $\begin{array}{l}\text { Agar pengendalian dapat } \\
\text { diterapkan sehingga } \\
\text { memperkecil risiko dari } \\
\text { ketidak-sesuaian } \\
\text { dokumen/barang yang } \\
\text { diterima. }\end{array}$ \\
\hline 3. & $\begin{array}{lr}\text { Tidak } & \text { adanya } \\
\text { pendistribusian } & \text { dokumen } \\
\text { ke bagian lain. } & \end{array}$ & $\begin{array}{l}\text { Memperbaharui prosedur di } \\
\text { bagian pembelian dengan } \\
\text { melakukan pendistribusian } \\
\text { dokumen ke bagian lain. }\end{array}$ & $\begin{array}{l}\text { Agar aktivitas bagian } \\
\text { pembelian } \\
\text { terkendali dan terawasi } \\
\text { oleh beberapa bagian } \\
\text { yang ada di perusahaan. }\end{array}$ \\
\hline 4. & $\begin{array}{l}\text { Tidak adanya dokumen } \\
\text { pengeluaran barang pada } \\
\text { saat mengirimkan barang } \\
\text { dari supplier ke bagian } \\
\text { pengiriman dan perakitan. }\end{array}$ & $\begin{array}{l}\text { Memperbaharui prosedur di } \\
\text { bagian pembelian dengan } \\
\text { harus membuat dokumen } \\
\text { pengeluaran barang pada saat } \\
\text { mengirimkan barang yang } \\
\text { diterima dari supplier ke } \\
\text { bagian pengiriman dan } \\
\text { perakitan dan membuatkan } \\
\text { desain dokumen pengeluaran } \\
\text { barang sesuai standar dokumen } \\
\text { yang baik dan benar. }\end{array}$ & $\begin{array}{lr}\text { Agar } & \text { proses } \\
\text { pengendalian dibagian } \\
\text { ini dapat diterapkan } \\
\text { dengan baik dan dengan } \\
\text { prosedur ini } \\
\text { memudahkan aktivitas } \\
\text { dibagian lain tidak } \\
\text { terhambat akibat kurang } \\
\text { baiknya penyampaian } \\
\text { informasi di bagian ini. }\end{array}$ \\
\hline 5. & $\begin{array}{lr}\text { Tidak adanya } & \text { prosedur } \\
\text { pembuatan } & \text { laporan } \\
\text { pembelian di } & \text { bagian } \\
\text { pembelian. } & \end{array}$ & $\begin{array}{l}\text { Memperbaharui prosedur di } \\
\text { bagian pembelian dengan } \\
\text { harus melakukan pelaporan } \\
\text { seluruh kegiatan pembeliannya } \\
\text { ke dalam laporan pembelian. }\end{array}$ & $\begin{array}{lr}\text { Agar aktivitas di bagian } \\
\text { pembelian } \\
\text { dipertanggung-jawabkan } \\
\text { oleh bagian pembelian } \\
\text { terutama } \\
\text { direktur. }\end{array}$ \\
\hline
\end{tabular}




\begin{tabular}{|c|c|c|c|}
\hline 1. & $\begin{array}{l}\text { Tidak adanya prosedur } \\
\text { pencocokan dokumen } \\
\text { atau barang yang diterima } \\
\text { dengan dokumen yang } \\
\text { ada. }\end{array}$ & $\begin{array}{l}\text { Memperbaharui prosedur } \\
\text { pencocokan dokumen atau } \\
\text { barang dengan dokumen yang } \\
\text { telah diarsipkan. }\end{array}$ & $\begin{array}{l}\text { Agar pengendalian dapat } \\
\text { diterapkan sehingga } \\
\text { memperkecil risiko dari } \\
\text { ketidak-sesuaian } \\
\text { dokumen/barang yang } \\
\text { diterima. }\end{array}$ \\
\hline 2. & $\begin{array}{l}\text { Tidak adanya dokumen } \\
\text { bukti penerimaan barang } \\
\text { yang dibuat di bagian } \\
\text { pengiriman dan perakitan }\end{array}$ & $\begin{array}{l}\text { Memperbaharui prosedur di } \\
\text { bagian pengiriman dan } \\
\text { perakitan dengan membuat } \\
\text { dokumen bukti penerimaan } \\
\text { barang yang sesuai dengan } \\
\text { standar dokumen yang baik } \\
\text { dan benar pada saat menerima } \\
\text { barang dari bagian pembelian } \\
\text { atas barang yang harus dikirim } \\
\text { dan dirakit oleh bagian } \\
\text { pengiriman dan perakitan. }\end{array}$ & $\begin{array}{l}\text { Agar pengendalian dapat } \\
\text { diterapkan oleh bagian } \\
\text { pengiriman dan } \\
\text { perakitan sehingga tidak } \\
\text { menghambat aktivitas } \\
\text { bagian lain akibat dari } \\
\text { lambatnya informasi } \\
\text { yang diterima atas } \\
\text { konfirmasi barang telah } \\
\text { diterima dengan bukti } \\
\text { yang sesuai standar. }\end{array}$ \\
\hline 3. & $\begin{array}{l}\text { Tidak adanya dokumen } \\
\text { surat jalan yang dibuat di } \\
\text { bagian pengiriman dan } \\
\text { perakitan }\end{array}$ & $\begin{array}{l}\text { Memperbaharui prosedur } \\
\text { bagian pengiriman dan } \\
\text { perakitan dengan membuat } \\
\text { dokumen surat jalan pada saat } \\
\text { pengiriman dan perakitan akan } \\
\text { dilakukan dengan } \\
\text { memperbaharui format surat } \\
\text { jalan yang sudah ada dari } \\
\text { bagian penjualan menjadi lebih } \\
\text { baik sesuai dengan standar } \\
\text { dokumen yang baik dan benar. }\end{array}$ & $\begin{array}{l}\text { Agar informasi yang } \\
\text { dihasilkan dari bagian } \\
\text { pengiriman dan } \\
\text { perakitan atas kegiatan } \\
\text { yang telah dilakukan } \\
\text { sangat informatif, efektif } \\
\text { dan efisien sehingga bisa } \\
\text { meningkatkan kinerja } \\
\text { dari setiap bagian di } \\
\text { perusahaan. }\end{array}$ \\
\hline 4. & $\begin{array}{lr}\text { Tidak } & \text { adanya } \\
\text { pendistribusian } & \text { dokumen } \\
\text { ke bagian lain. } & \end{array}$ & $\begin{array}{l}\text { Memperbaharui prosedur di } \\
\text { bagian pembelian dengan } \\
\text { melakukan pendistribusian } \\
\text { dokumen ke bagian lain. }\end{array}$ & $\begin{array}{l}\text { Agar aktivitas bagian } \\
\text { pembelian } \\
\text { terkendali dan terawasi } \\
\text { oleh beberapa bagian } \\
\text { yang ada di perusahaan. }\end{array}$ \\
\hline 5. & $\begin{array}{l}\text { Tidak adanya prosedur } \\
\text { pembuatan laporan } \\
\text { pengiriman dan perakitan } \\
\text { di bagian pengiriman dan } \\
\text { perakitan. }\end{array}$ & $\begin{array}{l}\text { Memperbaharui prosedur di } \\
\text { bagian pengiriman dan } \\
\text { perakitan dengan harus } \\
\text { melakukan pelaporan seluruh } \\
\text { kegiatan pengiriman dan } \\
\text { perakitannya ke dalam laporan } \\
\text { pengiriman dan perakitan. }\end{array}$ & $\begin{array}{l}\text { Agar aktivitas di bagian } \\
\text { pengiriman dan } \\
\text { perakitan dapat } \\
\text { dipertanggung-jawabkan } \\
\text { oleh bagian pengiriman } \\
\text { dan perakitan terutama } \\
\text { kepada direktur. }\end{array}$ \\
\hline
\end{tabular}




\section{Kesimpulan}

Berdasarkan hasil penelitian yang telah dilakukan, berikut kesimpulan yang dapat diambil :

Penerapan sistem informasi pada CV X masih kurang baik. Alasan dikatakan masih kurang baik karena ditemukan beberapa kelemahan-kelemahan serta kendala yang dihadapi, baik permasalahan secara umum maupun secara khusus dalam menjalankan kegiatan operasional perusahaan.

Permasalahan yang tedapat pada sistem informasi CV X terbagi menjadi beberapa permasalahan yang terkait dengan tidak adanya struktur organisasi dan uraian tugas yang menyebabkan kurang terkontrolnya tugas dan fungsi serta tanggung jawab dari setiap bagian. Hal ini berdampak pada adanya perangkapan tugas dan fungsi maupun jabatan pada bagian penjualan yang mengakibatkan kemungkinan besar terjadinya kesalahan dalam menjalankan tugas maupun pencatatan. Masalah selanjutnya didalam CV X yakni berkaitan dengan input, process, dan output dimana input yang digunakan seluruh kegiatan bisnis perusahaan masih kurang maksimal, karena dokumen yang digunakan masih kurang baik dalam hal ketersediaannya maupun formatnya yang sebagian besar masih tidak sesuai dengan standar yang baik dan benar. Hal ini terjadi karena pada proses atau prosedur yang diterapkan pada saat melakukan aktivitas masih kurang adanya pengendalian dan pengawasan dari setiap aktivitas. Sedangkan kelemahan yang ada dalam bentuk output yaitu hampir semua bagian tidak membuat laporan kegiatannya seperti laporan penjualan (yang masih berupa rekap sederhana), laporan pembelian, laporan pengiriman dan perakitan.

Berdasarkan masalah yang ditemukan didalam perusahaan CV X, analis/peneliti membuatkan model rancangan sistem informasi yang terkait dengan bagian penjualan, pembelian, dan pengiriman \& perakitan, dengan harapan memberikan kemudahan dalam kegiatan operasional pada CV X. Adapun model perancangan yang dibuat oleh peneliti adalah sebagai berikut :

1. Membuat struktur organisasi dari CV X Secara Tertulis.

2. Membuat uraian tugas dari seluruh bagian di dalam CV X secara tertulis.

3. Membuat model dari input sistem seperti : (1) Order Penjualan, (2) Faktur Penjualan, (3) Kwitansi, (4) Order Pembelian, (5) Bukti Pengeluaran Barang, (6) Bukti Penerimaan Barang, (7) Surat Jalan.

4. Membuat model prosedur sistem seperti : (1) Flowchart sistem dan prosedur Penjualan, (2) Pembelian, (3) Pengiriman dan Perakitan.

5. Membuat model output sistem seperti : (1) Laporan Penjualan, (2) Laporan Pembelian, (3) Laporan Pengiriman dan Perakitan.

\section{Acknowledge}

Terima kasih kepada seluruh dosen prodi akuntansi Universitas Islam Bandung yang telah membimbing dalam menyelesaikan penelitian ini dan kepada seluruh teman-teman penulis yang selalu memberi dukungan dan dorongan

\section{Daftar Pustaka}

[1] Sekaran. Bougie. 2013. Research Methods for Business: A skill Building Approach. Edisi 5 New York: John wiley@Sons

[2] Taylor, Liz. 2020. International Encyclopedia of Human Geography (Second Edition). University of Cambridge, Cambridge, United Kingdom.

[3] Whitten, Jeffrey L \& Lonnie, D Bentley. 2004. System Analysis and Design Methods. New York: McGrwaw-Hill Irwin 4. A. Shimp T. Periklanan Promosi: Aspek Tambahan Komunikasi Pemasaran Terpadu. 5th ed. Jakarta: Erlangga; 2000. 